\title{
Creation of Learning Opportunities for Electrical Engineering Students at Northern Cape Urban Technical Vocational Education and Training College
}

\author{
Thomas Masvosve ${ }^{1, *}$, Moeketsi Mosia ${ }^{2}$, Johane Hlatywayo ${ }^{3}$ \\ ${ }^{1}$ School of Education, Sol Plaatje University, Kimberley, 8301, Northern Cape, South Africa \\ ${ }^{2}$ Centre for Teaching, Learning \& Programme Development, Sol Plaatje University, Kimberley, 8301, Northern Cape, South Africa \\ ${ }^{3}$ School of Natural \& Applied Sciences, Sol Plaatje University, Kimberley, 8301, Northern Cape, South Africa
}

Received March 8, 2021; Revised April 12, 2021; Accepted May 23, 2021

\section{Cite This Paper in the following Citation Styles}

(a): [1] Thomas Masvosve, Moeketsi Mosia, Johane Hlatywayo, "Creation of Learning Opportunities for Electrical Engineering Students at Northern Cape Urban Technical Vocational Education and Training College," Universal Journal of Educational Research, Vol. 9, No. 6, pp. 1197-1213, 2021. DOI: 10.13189/ujer.2021.090609.

(b): Thomas Masvosve, Moeketsi Mosia, Johane Hlatywayo (2021). Creation of Learning Opportunities for Electrical Engineering Students at Northern Cape Urban Technical Vocational Education and Training College. Universal Journal of Educational Research, 9(6), 1197-1213. DOI: 10.13189/ujer.2021.090609.

Copyright $\bigcirc 2021$ by authors, all rights reserved. Authors agree that this article remains permanently open access under the terms of the Creative Commons Attribution License 4.0 International License

\begin{abstract}
Technical and Vocational Education and Training (TVET) colleges are currently not succeeding in developing requisite skills in Electrical Engineering Studies. The aim of this study was to investigate opportunities to learn (OTL) created for Electrical Engineering students at a TVET College. The study was conducted using a mixed method case study where 101 questionnaires were distributed to all the students enrolled for N1 Electrical Trade Theory, and interviews conducted with 6 students purposively sampled based on their performance, and with the only lecturer teaching the subject. Document analysis was also employed to source vital curriculum information for the subject. The research resulted in a number of significant findings, namely; engineering theory lessons taught were not complemented by practical work or experiments, teaching methods and learning activities did not promote active participation on the part of students, classes were composed of both young and so-called mature students, there were not enough assessment opportunities and instructional resources. The research therefore, recommends that lecturers be appropriately qualified, so that they are informed about teaching and learning methods suitable for students of mixed abilities, ages and backgrounds; and that they employ teaching methods that are learning-centred, which result in students actively
\end{abstract}

creating knowledge through their own experiences. It is likely that the more a lecturer practices this type of teaching, and takes into consideration relevant contextual factors; the more s/he will enhance the creation of OTL for Electrical Engineering at a TVET college.

Keywords Curriculum, Electrical, Engineering, Perception, TVET

\section{Introduction}

South Africa is currently faced with serious socio-economic challenges such as poverty, inequality and high rate of unemployment. The Technical Vocational Education and Training (TVET) sector has been used by the government to prepare students to become functional workers in a particular vocational trade. According to the United Nations Educational, Scientific and Cultural Organization, UNESCO [1], the Technical Vocational Education and Training sector has two important objectives. The first is the social objective, concerned with the training and integration of young people within the labor market. The second is to contribute to the growth of the economy and creation of employment [1p2]. Globally, the TVET sector has had variable success in different 
countries. In East Asian countries such as Singapore, the TVET sector has been identified as a successful driver of industrialization [2]. Singapore has a TVET system that has been described by Seng [3] and Agrawal [4] as a "world-class model". The Singapore post-secondary education model consists of Junior Colleges, Polytechnics and Institutes of Technical Education (ITE); which enroll a combined total of about $90 \%$ of the graduates from the ten-year general education [5]. The Singapore Junior Colleges are equivalent to the South African Matric' National Senior Certification, while the combination of Polytechnics and Institutes of Technical Education (ITEs) is equivalent to the current TVET sector [5p21]. Education and training through polytechnics and ITEs have become the 'backbone' of Singapore's industrialization [4p23]. Similarly, the TVET sector has also become pivotal to the South African government's vision of accelerating skills development [5]. The White Paper on Post School Education and Training targets 1 million student enrolment in Community Education and Training (CET) colleges, 2.5 million in TVET colleges, and 1.6 million in Higher Education Institutions (HEIs) by 2030 [6].

However, in most sub-Saharan African countries (including South Africa), unlike in East Asian countries, TVET has, so far, played a peripheral role in skills development, despite its perceived prospects of combating youth unemployment and promoting economic growth [7]. Furthermore, the unemployment challenge in South Africa is worse than in many other emerging and developing economies as over three million young South Africans are not engaged in any form of education or work [8]. A study by Paterson, Keevy and Boka [9] found that South Africa's TVET colleges are largely attended by previously marginalized Black African youth, many of whom dropped out of school early and do not qualify for higher education. Those who qualify often face challenges related to limited financial resources to continue with studies resulting in them dropping out from higher education studies. This pattern is, however, likely to change if the recommendations of the 2016 Judge Heher Commission's inquiry into Higher Education and Training are implemented fully. The Commission recommends fee-free education for all TVET college students [10].

The main research question that this study addressed, was:

How does OTL affect student learning and engagement in Electrical Engineering at the NCU TVET College

In order to focus the study, the following two sub-questions were formulated:

- What are the main constructs of Opportunity to Learn (OTL)?

- What are the lecturer's and students' perceptions on the extent to which the enacted N1 Electrical Engineering curriculum creates Opportunity to Learn $(\mathrm{OTL})$ ?

\section{Background}

In 2002, the South African government established the TVET sector in terms of the Further Education and Training Act 98 of 1998, which involved former technical colleges, colleges of educators, and training centers being merged into 50 TVET colleges situated in all South Africa's nine provinces. The plan was to use the TVET system as a vehicle to transform the human resource needs of the country in relation to personal, social, civic and economic development [11]. This system would provide the vital intermediate to higher-level skills and competencies that South Africa desperately needs if it is to find its feet globally in the $21^{\text {st }}$ century $[12,13]$. However, Gewer [14] argues that, despite the well-meaning aim of the White Paper for Post-School Education and Training [6] to provide for effective training where it is needed, TVET colleges are currently failing to develop requisite skills in Electrical Engineering Studies effectively.

Some of the challenges that hinder the development of the expected skills include inadequate funding, which subsequently lead to inadequate teaching and learning resources, inappropriate instructional strategies, and inadequate lecturer qualifications [15,16]. Kraak [17] suggests that a combination of unprepared students, poor teaching and learning styles, and demanding electrical engineering subjects, results in low throughput rates at TVET colleges. This has seen a pattern of poor performance common in TVET colleges with certification rates of between $29 \%$ and $41 \%$ [18].

Without downplaying the challenges above, this paper argues that paucity of literature on student poor performance in the context of TVET is, in part, due to the limitations of a conceptual framework. It is our contention of this paper, that there is a need for a search of a framework which not only helps us to understand the outcomes of learning but equally important the process that yields these outcomes. Thus, in a search for such a framework this paper employs "Opportunity to Learn" known as OTL as a potential framework for understanding both the process and the outcome of learning. The challenges mentioned above are arguably traceable to the actual "opportunity to learn" created for TVET students in the classroom. OTL was initially defined as a measure of "whether or not students have had an opportunity to study a particular topic or for a test" [19]. However, more recently, it is used to refer to, not only the overlap between what has been taught and what is tested, but also to conditions under which learning takes place [20]. While OTL as a conceptual framework is used mainly to understand why learners in basic education perform poorly in mathematics, our choice to import it as a framework in the context of TVET is supported by Boscardin et al. [21] and Chabongora and Jita [22], who strongly argue that student achievement is closely linked to the creation of learning opportunities for them. 


\section{Literature Review}

The paper reviews literature on the role of OTL on skills development within a classroom context in a South African TVET college, particularly as it relates to students' achievement. This is so because the nature of learning opportunities created within the TVET college classroom has the potential to either enhance or hinder students' learning experiences as indicated extensively in literature [23-29]. A general question that can be asked is whether students are engaged in learning opportunities that enable them to create new knowledge or not. These opportunities are necessary to "create new meaning and to link existing knowledge to new knowledge, active exploration and collaborations and problems that elicit critical thinking skills" [30p2] in studying electrical engineering. Unesco [31p24] defines engineering as,

practice, profession and art that relates to the development, acquisition and application of technical, scientific and mathematical knowledge about the understanding, design, development, invention, innovation and use of materials, machines, structures, systems and processes for specific purposes.

Electrical engineering specifically deals with the exploitation of electrons and photons to produce artefacts that benefit humankind [32]. The design processes of these artefacts are based on scientific principles and theories that are normally best explained mathematically. This view is shared by Kamanzi [33] who traces the origins of electrical engineering to the "professionalization of branches of applied physics and mathematics as means to further develop technology harnessing the phenomena of energy, electricity and electromagnetic waves".

OTL can therefore, be summarized in three variables within the TVET College classroom, that is; curriculum content, instructional strategies and instructional resources [25]. Various studies on OTL have shown that these three overlapping variables have a significantly high impact on OTL in relation to student achievement [21,34].

Stabback [35] notes that curriculum comprises many elements of learning, which among others include; rationale, aims, content, methods, resources, time and assessment; and refers to various levels of planning and decision-making about learning, which link with many versions of learning (for example, intended, implemented, and attained). Bough [36] posits that it is this implemented curriculum, more than the intended curriculum that is central to the improvement of student performance. Curriculum content therefore, refers to what students are exposed to in a specific subject and topics essential for attaining standards or outcomes that are being assessed [35]. The curriculum content for TVET students expects them to acquire a high level of independence and comprehension of the entire work process and of the wider industry, and to incorporate both manual and intellectual tasks [37p635]. Three elements of curriculum content that appear to be prevalent in OTL are content coverage, content exposure, and content emphasis [38,39].

At the heart of instructional strategies are the teaching strategies, teaching methods and teaching techniques used to provide instruction [40,41] for students' academic success in electrical engineering. At the most basic level, the question that should be asked is whether students have been exposed to learning experiences with tasks through which their performance is to be judged. Morris et al. [42] state that the purpose of teaching is to support student learning. Research has shown that lecturers in the TVET sector usually possess technical qualifications as well as workplace experience and knowledge, but little pedagogical training, if any $[43,44]$. Such a factor may influence student engagement, and if it is negative, it could lead to students voluntarily withdrawing from college due to boredom, poor attendance and/or low achievement [45].

The lecturer has to be familiar with various teaching strategies that take into consideration the extent to which electrical engineering concepts have to be covered. It is crucial that lecturers teaching Electrical Trade Theory are knowledgeable about various teaching methods and strategies that take cognizance of complex electrical engineering concepts. These teaching strategies should promote deep learning characterized by students' intention to comprehend information by connecting ideas, emphasizing the importance of critical thinking, and creating own understanding of the subject under study [46].

Concerns about instructional resources relate to whether appropriate resources for preparing students to achieve the desired standards are available. The challenges facing education quality in Africa, in general, are closely related to both the shortage of resources for education, and the inefficient use of the available resources [47]. Quality classroom/laboratory facilities and equipment/tools are essential for the provision of quality TVET programmes. Field et al. [48] has noted that the TVET's NATED programmes in South Africa currently fail to offer TVET students the practical learning activities they need, because of inadequate infrastructure, such as workshop or laboratory equipment for engineering students. This lack of practical exposure by students, combined with lack of partnerships with the business sector, largely contribute to low employment possibilities for TVET graduates [48]. Additionally, instructors must be trained in the use of the Learning and Teaching Support Material (LTSM); and whether the materials are adequate, appropriate, coherent and complementary [49,50].

Based on the reviewed literature on OTL and TVET training, this paper argues that the kind of learning opportunities created within a TVET college classroom have the potential to either enhance or hinder students' learning experiences. It is what is taught and learnt inside the college classroom (the implemented curriculum) that eventually translates into observable and measurable outcomes, intended or otherwise. One of the critical 
variables in determining students' achievement in the TVET curriculum is their OTL.

\section{Research Methodology}

This section presents and provides the rationale for the research methodology that was chosen for this study. The study used a mixed method case study design. The section is divided into three main parts. The first part gives an overview of the research design, and is followed by a description of the population and sampling of research participants. The third part presents a summary of the research instruments, including how their reliability and validity were determined.

\section{Research Design}

This study used mixed method research, and a case study research design. For the mixed method research component, the researcher collected, analyzed, and integrated both quantitative and qualitative data into one study, in order to respond to the study questions, as suggested by Almalki [51]. This study used the partially mixed sequential research design $[52,53]$, since the quantitative data and qualitative data were collected in two phases. The first phase involved collecting the quantitative data, the results of which helped to inform the collection of qualitative data. Questionnaires were used to collect quantitative data and interviews were used to collect qualitative data. Qualitative data, which provided an in-depth insight into the students' and lecturer's opinions and beliefs [54], were collected through semi-structured interviews, and the analysis of the N1 Electrical Trade Theory syllabus and curriculum policies. As for the case study design component, the research focused on exploring OTL as contemporary social phenomenon [55] on a real situation (teaching and learning), with real people (TVET students and lecturer), in a real environment (classroom) for N1 subject, Electrical Trade Theory.

\section{Population and Sample}

The population for this study was 101 registered students taking the subject Electrical Trade Theory at a Northern Cape Urban TVET College. Quantitative data on constructs of OTL were collected from 90 students through questionnaires distributed in the first phase. Thereafter, qualitative data were collected from the interviews conducted with six purposively sampled students and the TVET college lecturer who taught the subject. In choosing the six students enrolled for electrical engineering, the focus was on students' performance as criterion. Three levels of student performance - lowest, middle and highest performers - were targeted. This approach is supported by [56], who argue that the application of purposive sampling requires the researcher to categorize subjects according to an identified criterion related to the research problem.

\section{Research Instruments}

The researcher collected data through questionnaires, analysis of relevant documents and face-to-face interviews. The questionnaire had three main sections, namely, a section collecting data on respondents' biographical characteristics, and one on the five main OTL constructs, and a section that elicited general comments. Items were formulated according to Likert-type scales and were balanced both sides of the neutral choice, providing some means of ranking the responses. The general comment section comprised open-ended questions. In order to acquire the meaning of OTL in the teaching and learning of N1 Electrical Trade Theory, the researcher analyzed the N1 Electrical Trade Theory syllabus, Internal Continuous Assessment (ICASS) guidelines, the subject lesson plan, and the Electrical Trade Theory textbook. Interviews were conducted in order to investigate "ideas, attitudes and even perceptions about the OTL phenomenon. Semi-structured interviews were conducted with six students and one lecturer. The same open-ended interview questions were asked to all six students, in an effort to produce consistent data. However, the questions were flexible enough to give the interviewer the opportunity to probe and expand on the interviewee's responses, while keeping the interview within the boundaries set by the aim of the study.

\section{Instrument Reliability}

The dependability of the questionnaires was determined by correlating the findings with the other sources of data collection, that is, document analysis and interviews. Interview schedules were also subjected to careful analysis by the researcher's study promoter and colleagues in the study group. The researchers also applied the Cronbach's alpha $(\alpha)$ to check for internal consistency and reliability [57] of all the questions, except for three items which had fewer than four items (see Table). In the case of the three items that had fewer than four items, the average inter-item correlation construct validity testing was applied. Average inter-item correlation $(r)$ is a test meant to determine whether different items measure the same construct [58], in this case, the content emphasis.

\section{Instrument Validity}

To ensure the research can be trusted on content validity, the researchers formulated questions carefully, by phrasing them in simple and straightforward language that avoided ambiguity. Even though an external independent party, the questions were also subjected to a thorough analysis by the expert, study promoter. The lecturer was also asked the same questions as those posed to the students. The lecturer's interview focused on how the lecturer would 
respond to some of the issues raised by students during their interview sessions.

Validity and reliability of the data and their interpretation were also augmented by collecting data and obtaining information through different sources, that is, students, and lecturer and relevant documents [59].

Table 1. Internal consistency reliability of the questionnaire

\begin{tabular}{|c|c|c|c|}
\hline OTL elements & Sub-elements & Cronbach's alpha $(\alpha)$ & $\begin{array}{c}\text { Average Inter-item } \\
\text { correlation }\end{array}$ \\
\hline $\begin{array}{l}\text { Content } \\
\text { exposure }\end{array}$ & $\begin{array}{l}\text { - Time utilisation (Item 5.1) } \\
\text { - Class attendance (Item 5.2) } \\
\text { - Remedial/enrichment opportunities (Item 5.3) } \\
\text { - Surface or deep learning (Item 5.4) }\end{array}$ & $\begin{array}{l}\qquad \alpha=0.70 \\
\text { (2 items omitted, } 5.3 .1 \text { is } \\
\text { qualitative and 5.3.2 not supposed } \\
\text { to be completed by all) }\end{array}$ & \\
\hline $\begin{array}{l}\text { Content } \\
\text { emphasis }\end{array}$ & $\begin{array}{l}\text { - Emphasis on levels of difficulty (Item 4.1) } \\
\text { - Textbooks and other LTSM (Item 4.2) } \\
\text { - All topics emphasised the same (Item 4.3) }\end{array}$ & & $r=0.69$ \\
\hline $\begin{array}{l}\text { Content } \\
\text { coverage }\end{array}$ & - Content coverage & $\begin{array}{c}\alpha \text { not calculated since its one item } \\
\text { only }\end{array}$ & $\begin{array}{l}r \text { not calculated since } \\
\text { its one item only }\end{array}$ \\
\hline $\begin{array}{l}\text { Quality of } \\
\text { instruction }\end{array}$ & $\begin{array}{l}\text { - Teaching methods (Item 7.1) } \\
\text { - Theory complemented with practice (Item 7.2) } \\
\text { - Lesson coherence (Item 7.3) } \\
\text { - Lecturer always in command of subject (Item 7.4) } \\
\text { - Students 'participation in class activities (Item 7.7) } \\
\text { - Lecturer's talking time (Item 7.8) } \\
\text { - Lesson pacing (Item 7.9) } \\
\text { - Lessons relate to students' background (Item 7.10) } \\
\text { - Lecturer organises information in logical sequence (Item } \\
\text { 7.11) } \\
\text { - Grouping strategies enable students to work together } \\
\text { (Item 7.12) }\end{array}$ & $\begin{array}{l}\qquad \alpha=0.69 \\
\text { (2 items were omitted, } 7.5 \text { and } 7.6, \\
\text { as they are qualitative in nature) }\end{array}$ & \\
\hline $\begin{array}{l}\text { Instructional } \\
\text { resources }\end{array}$ & $\begin{array}{l}\text { - Access to specialised equipment, facilities and } \\
\text { classrooms (Item 8.2) } \\
\text { - Workshops and laboratories are equipped with equipment } \\
\text { that uses modern technology (Item 8.3) } \\
\text { - Support is received during workshop or laboratory } \\
\text { sessions (Item 8.4) }\end{array}$ & $\begin{array}{l}\qquad \alpha=0.88 \\
(1 \text { item, that is, } 8.1 \text {, omitted as } \\
\text { data responses are unloadable })\end{array}$ & \\
\hline
\end{tabular}




\section{Results}

In this study, the focus was on how the topics in the subject N1 Electrical Trade Theory were weighted. Table 2 presents the content topics of the N1 Electrical Trade Theory subject. As shown in Table 2, all 10 topics are allocated weighted values. The weighted values of these topics provide an indication of the percentage of the total content on the topic, and time that should be made available for the instruction that is to be spent.

Table 2. Content topics of the N1 subject Electrical Trade Theory

\begin{tabular}{|c|c|c|}
\hline Module (Topic) & Description & Weight Value $\% \pm$ \\
\hline 1 & Safety and basic hand tools & 10 \\
\hline 2 & Electrical circuits & 12 \\
\hline 3 & Magnetism and transformers & 10 \\
\hline 4 & $\begin{array}{c}\text { Batteries and direct current } \\
\text { sources }\end{array}$ & 10 \\
\hline 5 & Alternating current & 8 \\
\hline 6 & Measuring instruments & 6 \\
\hline 7 & $\begin{array}{c}\text { Conductors, cables and wire } \\
\text { ways }\end{array}$ & 10 \\
\hline 8 & Wiring of premises & 18 \\
\hline
\end{tabular}

Source: RSA Education and Culture Service [60p4]

Table 2 shows the summary of the other main quantitative results on elements of curriculum content. A total of $83.4 \%$ indicated that all the topics were treated the same. In other words, questionnaire respondents were of the perception that all 10 topics were being treated with the same weighting (see Table 2C). This is contrary to the stipulations of the syllabus. The weighting of topics is important, because it is the primary indicator of how much work, teaching time and marks have to be allocated to a specific topic. However, during the interviews (see Table 3 ), it was determined that certain topics, such as transformers and magnetism, electrical circuits, and safety and basic hand tools; received more attention than other topics. Surprisingly, not even a single student mentioned the topic, "Wiring of premises", which is regarded as having the greatest weighting by the syllabus $(18 \%)$. This finding suggests that the enacted curriculum for Electrical Trade Theory is not consistent with the intended curriculum.

Questionnaire responses on content emphasis showed that a significant percentage (33\%) of respondents indicated that activities given to students at N1 level related mainly to lower cognitive levels (see Table2A). A total of $88.9 \%$ $(52.2 \%$ plus $36.7 \%)$ of respondents opined that the teaching and learning materials were very helpful (see Table 2B). This was not surprising, because the topics in the main textbook used for Electrical Trade Theory lessons are the same as the topics in the syllabus. A positive finding on content exposure was that, students viewed the time allocated for Electrical Trade Theory as being spent on actual teaching and learning experiences (see Table 2D). This finding was complemented by another finding on the perception that students attended their classes. It would seem that there was a positive relationship between spending class time on actual learning, and attendance, as students attend because it is worth their while to attend classes. These findings were positive, considering that time on task and attendance are two of the basic requirements for creating OTL. Questionnaire Findings on content coverage also showed that, in the main, most respondents believed that all the curriculum content had been covered. As for the extent to which the content was covered, the researcher had to determine this from the interviews.

Table 3. Main results on elements of curriculum content

Table 3A. Responses on the question "Great emphasis is placed on which level of difficulty of your academic work in N1 Electrical Trade Theory?"

\begin{tabular}{|c|c|c|c|}
\hline Level of difficulty & Frequency & Percent & $\begin{array}{c}\text { Cumulative } \\
\text { Percent }\end{array}$ \\
\hline Lower order only (1) & 30 & 33.0 & 33.0 \\
\hline Higher order only (2) & 5 & 6.0 & 39.0 \\
\hline $\begin{array}{c}\text { Both lower and higher } \\
\text { order (3) }\end{array}$ & 55 & 61.0 & 100 \\
\hline TOTAL & 90 & 100.0 & \\
\hline
\end{tabular}

\begin{tabular}{|c|c|c|}
\hline \multirow{2}{*}{$\mathbf{N}$} & Valid & 90 \\
\cline { 2 - 3 } & Missing & 0 \\
\hline \multicolumn{2}{|c|}{ Mean } & 2.28 \\
\hline \multicolumn{2}{|c|}{ Standard deviation } & 0.93 \\
\hline
\end{tabular}

Table 3B. Responses on the statement "Textbooks and teaching and learning materials prepared by lecturers are effective on the teaching and learning of the content for N1 Electrical Engineering (Electrical Trade Theory) studies"

\begin{tabular}{|c|c|c|c|}
\hline Usefulness of LTSM & Frequency & Percent & $\begin{array}{c}\text { Cumulative } \\
\text { Percent }\end{array}$ \\
\hline Strongly disagree (1) & 1 & 1.1 & 1.1 \\
\hline Disagree (2) & 5 & 5.6 & 6.7 \\
\hline Unsure (3) & 4 & 4.4 & 11.1 \\
\hline Agree (4) & 47 & 52.2 & 63.3 \\
\hline Strongly agree (5) & 33 & 36.7 & 100 \\
\hline TOTAL & 90 & 100 & \\
\hline
\end{tabular}

\begin{tabular}{|c|c|c|c|}
\hline \multirow{2}{*}{$\mathbf{N}$} & Valid & & 90 \\
\cline { 2 - 4 } & Missing & & 0 \\
\hline Mean & & 4.18 \\
\hline \multicolumn{2}{|c|}{ Standard deviation } & & 0.84 \\
\hline
\end{tabular}


Table 3C. Responses on the statement "All topics within the N1 Electrical Engineering (Electrical Trade Theory) studies curriculum are emphasized the same by your lecturers".

\begin{tabular}{|c|c|c|c|}
\hline $\begin{array}{c}\text { Same emphasis on } \\
\text { all the topics }\end{array}$ & Frequency & Percent & $\begin{array}{c}\text { Cumulative } \\
\text { Percent }\end{array}$ \\
\hline $\begin{array}{c}\text { Strongly disagree } \\
(1)\end{array}$ & 0 & 0 & 0 \\
\hline Disagree (2) & 3 & 3.3 & 3.3 \\
\hline Unsure (3) & 12 & 13.3 & 16.6 \\
\hline Agree (4) & 58 & 64.5 & 81.1 \\
\hline Strongly agree (5) & 17 & 18.9 & 100.0 \\
\hline TOTAL & 90 & 100.0 & \\
\hline
\end{tabular}

\begin{tabular}{|c|c|c|}
\hline \multirow{2}{*}{$\mathbf{N}$} & Valid & 90 \\
\cline { 2 - 3 } & Missing & 0 \\
\hline \multirow{2}{*}{ Mean } & 3.99 \\
\hline \multicolumn{2}{|c|}{ Standard deviation } & .675 \\
\hline
\end{tabular}

Table 3D. Responses on the statement "Allocated time for teaching and learning is spent on the actual teaching and learning of N1 electrical engineering (Electrical Trade Theory) studies

\begin{tabular}{|c|c|c|c|}
\hline $\begin{array}{c}\text { Allocated time spent on } \\
\text { actual teaching and } \\
\text { learning }\end{array}$ & Frequency & Percent & $\begin{array}{c}\text { Cumulative } \\
\text { Percent }\end{array}$ \\
\hline Strongly disagree (1) & 1 & 1.1 & 1.1 \\
\hline Disagree (2) & 3 & 3.3 & 4.4 \\
\hline Unsure (3) & 2 & 2.2 & 6.7 \\
\hline Agree (4) & 50 & 55.6 & 62.2 \\
\hline Strongly agree (5) & 34 & 37.8 & 100.0 \\
\hline TOTAL & 90 & 100.0 & \\
\hline
\end{tabular}

\begin{tabular}{|c|c|c|}
\hline \multirow{2}{*}{$\mathbf{N}$} & Valid & 90 \\
\cline { 2 - 3 } & Missing & 0 \\
\hline \multicolumn{2}{|c|}{ Mean } & 4.26 \\
\hline \multicolumn{2}{|c|}{ Standard deviation } & .758 \\
\hline
\end{tabular}

Table 4. Interviewed students' perceptions of content coverage

\begin{tabular}{|c|c|c|}
\hline Theme 1 & Category & Detailed responses \\
\hline \multirow{7}{*}{$\begin{array}{l}\text { Content } \\
\text { coverage }\end{array}$} & \multicolumn{2}{|r|}{ Extent of content coverage } \\
\hline & $\begin{array}{l}\text { - Skipping topics } \\
\text { - Self-regulated learning }\end{array}$ & $\begin{array}{l}\text { Ok, I think Meneer [lecturer] has done them all but there are some of them that he } \\
\text { skipped and he said they are for self-study (ISB) }\end{array}$ \\
\hline & - Topic coverage & $\begin{array}{l}\text { No, out of } 100 \% \text {, about } 70 \% \text { are covered. The ones on Tools are covered, the measuring } \\
\text { instruments, ammeters, voltmeters are not covered and transformers should be covered } \\
\text { more (ISD) }\end{array}$ \\
\hline & - Use of textbook for lesson & We did cover the whole book you just requires more study (ISC) \\
\hline & \multirow{3}{*}{ - All topics covered } & $\begin{array}{l}\text { No, everything is fine with Trade Theory I don't have any complain everything is } \\
\text { covered (ISE) }\end{array}$ \\
\hline & & Yes Sir we go actually through most of the stuff, we cover most of the stuff (ISA) \\
\hline & & Yah, we covered them all (ISF) \\
\hline
\end{tabular}

Interview questions were similar to the items on the questionnaire for triangulation purposes. Coding for students' interview data started with the student ID, followed by the line number. For example, ISA indicates Interviewee Student number $\mathbf{1}$ and ISB was Interviewee Student number $\mathbf{2}$ and up to the last student to be interviewed, ISF. Four themes brought together in the interviews on OTL focused on what TVET lecturers do in their classrooms when they are teaching students. These themes were (1) content coverage; (2) content exposure; (3) content emphasis; and (4) instructional strategies. Extracts on curriculum content OTL construct from the students' interviews are shown from Table 4 to Table 6.

One item enquired about the perceptions of students regarding the amount of curriculum content that was covered in the Electrical Trade Theory subject. Table 4 presents key results in this regard.

In the main, it seems all the topics were covered. Thus, by covering all the topics, opportunities to learn were created in as far as content coverage is concerned. However, covering all the content or topics is not enough to create effective OTL. Attention should also be paid to the way the allocated time is utilized, whether there is surface learning or deep learning, and whether enrichment activities are provided to students.

Students were also asked three questions intended to provide a better understanding of their perceptions of content exposure. These questions sought to establish their perceptions of time allocation, enrichment activities, and whether there was deep or surface learning. Extracts in Table 5 present key students' perceptions regarding content exposure. 
Table 5. Interviewed students' perceptions of content exposure

\begin{tabular}{|c|c|c|}
\hline Theme 2 & Category & Detailed responses \\
\hline \multirow{13}{*}{$\begin{array}{c}\text { Content } \\
\text { exposure }\end{array}$} & \multicolumn{2}{|l|}{ Task-on-task } \\
\hline & - Time utilization & We spend most of the time teaching and learning (ISA) \\
\hline & $\begin{array}{l}\text { - Questioning opportunity } \\
\text { - Classroom management } \\
\text { skills }\end{array}$ & $\begin{array}{l}\text { I think Meneer [lecturer] done his work and then he spends his time on teaching and he give us } \\
\text { the chance to ask questions and to add something if we have, Yah. But, the problem with me } \\
\text { this that he is not too strict that is why some of the students do not take him serious. I think he } \\
\text { has to be a bit strict so that all students can obey and respect him. It's like they are taking } \\
\text { advantage of him (ISB) }\end{array}$ \\
\hline & - Trimester too short & $\begin{array}{l}\text { The time is not that much maybe because it's a trimester thing that's why I said study has to be } \\
\text { there full time because you study for two months and next month you have to write the exam } \\
\text { so it's a bit hard. In class I would say } 90 \% \text { of the time (ISC) }\end{array}$ \\
\hline & \multirow{3}{*}{$\begin{array}{l}\text { - Fraction of the time spent on } \\
\text { actual teaching and learning } \\
\text { - Classroom management } \\
\text { skills } \\
\text { - Students' negative attitude } \\
\end{array}$} & Out of $100 \%$, about $80 \%$ is spent on the actual teaching and learning in class" (ISD) \\
\hline & & Definitely, I would say $80 \%$ (ISE) \\
\hline & & $\begin{array}{l}\text { Most of the time for me because I am always doing my work. For all the student in class, say } \\
\text { its } 50 \% \text { of the time there are doing their work and the rest of the time, some of them just wait } \\
\text { for the time to pass and out they go. Some of them are not serious (ISF) }\end{array}$ \\
\hline & \multicolumn{2}{|l|}{ Enrichment activities } \\
\hline & - Homework & $\begin{array}{l}\text { They [lecturer] give us homework (ISA) We receive some homework (ISB) } \\
\text { Yah, there are some exercises we do at home (ISC) Yes, we receive homework (ISD) } \\
\text { Yes, we have homework (ISE) }\end{array}$ \\
\hline & - Frequency of homework & $\begin{array}{l}\text { Most of the time (ISA) A lot of times (ISB) Few of times (ISC) } \\
\text { Almost every day (ISD) }\end{array}$ \\
\hline & $\begin{array}{l}\text { - Homework at the end of each } \\
\text { chapter } \\
\text { - Self-assessment } \\
\text { - Student attitude } \\
\text { - Monitoring and feedback of } \\
\text { homework }\end{array}$ & $\begin{array}{l}\text { It depends with what chapter are we at and then after we finish that chapter we will get the } \\
\text { homework (ISE) } \\
\text { We usually get homework (sic) but it depends on the student, if they do or don't alright, } \\
\text { yes, because there are self-evaluation tasks that we have to do so if you don't do it that's why I } \\
\text { am saying it depends on the students if they wanna [want to] do or not. If the student does not } \\
\text { do the teacher will continue teaching and yah that's why I am saying it's up to the student if } \\
\text { they do it because he can say do the exercise and they do not do (ISF) }\end{array}$ \\
\hline & \multicolumn{2}{|l|}{ Deep or surface learning } \\
\hline & & $\begin{array}{l}\text { We go deep but not that deep, but we cover like most deep, we actually go deep (ISA) Yah, on } \\
\text { the surface (ISC) } \\
\text { Surface (ISD) } \\
\text { No, we don't go deeper (ISE) }\end{array}$ \\
\hline
\end{tabular}

One of the key findings of the study was that students perceived the time available to study the subject (a trimester) as too little. Most of them indicated that their class time was spent on actual teaching and learning. The interviews confirmed that students were given homework and past examination question papers, which they considered as enrichment activities. When the respondents were asked whether they had tutors or had received instructions on computers, they all indicated that they had not. This response indicated that students may not have received extra assistance when they needed it. However, student ISF added the following, with regard to tutor help:

INTERVIEWEE STUDENT F: No, usually we ask those who know, we just ask our [fellow students] in class (ISF).

This answer confirms that students needed extra assistance from time to time. Working in groups could go a long way to creating the much-needed OTL. Respondent ISF made the following statement about the use of computers:

INTERVIEWEE STUDENT F: Yah, if we have like assignments and like the question papers they gave us now it would be fine if we were to get them on computers but just like this no, it's not necessary for that (ISF)

It was interesting to note that students compared their department to other departments and, in general, would appreciate using computers for instruction and general work, including assignments - that is, if they were to receive assignments, as they did not do assignments at the time of the conduct of the interview.

Three questions were also asked to the students in order to gain a better understanding of their perceptions of content emphasis. The questions for this section sought to establish students' perceptions on topic emphasis, types of cognitive skills exposed, and usefulness of the teaching and learning material. Extracts in Table 6 reveal key findings about students' perceptions of content emphasis. 
Table 6. Interviewed students' perceptions on content emphasis

\begin{tabular}{|c|c|c|}
\hline Theme 3 & Category & Detailed responses \\
\hline \multirow{10}{*}{$\begin{array}{c}\text { Content } \\
\text { emphasis }\end{array}$} & \multicolumn{2}{|l|}{ Topic emphasis } \\
\hline & \multirow{2}{*}{$\begin{array}{l}\text { - Magnetism and transformers } \\
\text { - Electrical circuits } \\
\text { - Safety and basic hand tools } \\
\text { - Batteries and DC sources } \\
\text { - Magnetism } \\
\text { - Electronics } \\
\text { - Setting of exam questions }\end{array}$} & $\begin{array}{l}\text { The topics about the circuits and magnetism (ISA) Magnetic field, Ohm's law and the circuits } \\
\text { (ISD) }\end{array}$ \\
\hline & & $\begin{array}{l}\text { Safety, and the ones where they talk about the batteries and the magnetism and capacitors, ones } \\
\text { which involves calculations and definitions also so that you mustn't forget because usually they } \\
\text { confuse you so you have to stay focused that's why they always emphasize on those ones that } \\
\text { involve calculations and definitions (ISF) }\end{array}$ \\
\hline & \multicolumn{2}{|c|}{ Any difference between tasks for cognitive skills } \\
\hline & \begin{tabular}{|l|} 
\\
- Challenging tasks \\
- Tasks develop different \\
cognitive skills
\end{tabular} & $\begin{array}{l}\text { Sometimes easy but most of the time difficult (ISA) They are not the same you can see that } \\
\text { difference (ISB) Yah, there is a difference (ISC) } \\
\text { Yah, I see the difference (ISD) } \\
\text { Yah, definitely (ISE) Yes (ISF) }\end{array}$ \\
\hline & \multicolumn{2}{|r|}{ Usefulness of the teaching and learning material } \\
\hline & - Useful & They do [assist] a lot' (ISA) They do help much (ISD) Yes, definitely (ISE) \\
\hline & \multicolumn{2}{|c|}{ Usefulness of the teaching and learning material } \\
\hline & $\begin{array}{l}\text { Exam predictability and } \\
\text { spotting (selective learning) }\end{array}$ & $\begin{array}{l}\text { Ok, to me is that if you focus on studying on the textbook not on the past question papers you will } \\
\text { be doomed because the way people set the papers they set based on the things they always set } \\
\text { like on the past question papers so you need to focus on the past question papers than on what is } \\
\text { in the book so, and what the teachers teach is based on what appears on the exam papers so to me } \\
\text { teachers are better than the textbooks because the textbook has a lot of information that is not } \\
\text { needed for us to study because some of it does not appear in our question papers (ISB) }\end{array}$ \\
\hline & - Opportunity to ask question & $\begin{array}{l}\text { For me, I would say they help me lot because usually when I am busy with them if I don't } \\
\text { understand I get to ask questions but I don't know for other students because I hardly see them } \\
\text { asking question. It's not all of them but some of them so I would say but they pass but they hardly } \\
\text { ask questions so I wouldn't say they are not doing their work. Maybe they are afraid to ask the } \\
\text { lecturer then they go ask another student so (ISF) }\end{array}$ \\
\hline
\end{tabular}

A summary of the main quantitative results on instructional strategies is shown in Figure 1. A total of almost $89 \%$ indicated that the lecturer did not vary his teaching methods (see Figure 1A). While the lecturer employed the lecture method, demonstration method and videos, other appropriate teaching methods were not employed. Examples are those teaching methods that develop collaborative and teamwork skills, such as the group work teaching method. Another finding was that theory was not complemented with practical work and experiments (see Figure 1B), making understanding of complex electricity concepts much harder. This seems to agree with Gewer [14]'s observation that TVET colleges are currently failing to manage the development of practical skills in engineering studies effectively. The syllabus was also found to play a major role in a situation where theory was not complemented with practical work, in failing to stipulate the necessary psychomotor skills.

When students were asked what could be improved to create effective opportunities to learn, they said that the classes needed practical experiences. It was clear that N1 Electrical Trade Theory students were in desperate need of more practical work, and experimental learning opportunities to be integrated in their syllabus. They would, likewise, appreciate more exposure to what is happening in industry, through strategies such as excursions. It can be assumed that, if experiments and practical work experience are assigned, students would consider them to be effective OTL. Most respondents indicated that the lessons were coherent and the lecturer was in command of the subject knowledge (see Figure 1D). However, the study determined that students were not actively involved in teaching and learning activities, as the lecturer's pedagogy tended to be teacher-centered (see Figure 1C). 


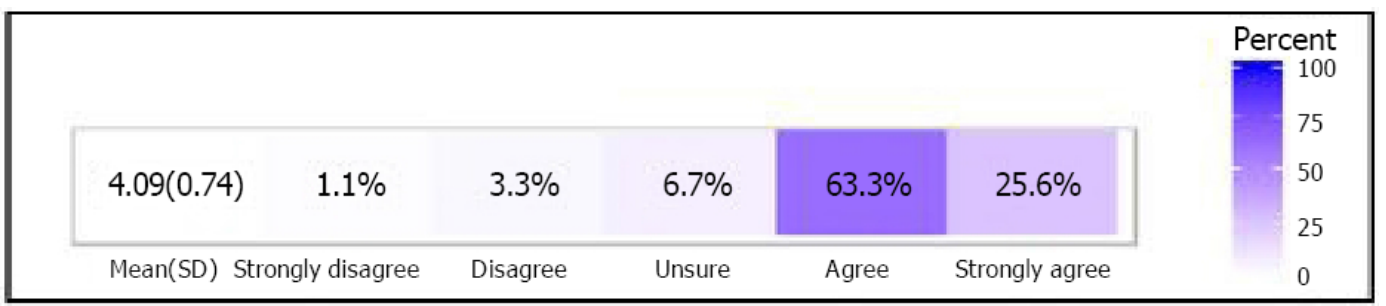

Figure 1A. Responses to the statement "Teaching methods are varied"

\begin{tabular}{|c|c|c|c|c|c|c|}
\hline & & & & & & $\begin{array}{l}\text { Percent } \\
100\end{array}$ \\
\hline $3.32(1.15)$ & $5.6 \%$ & $23.3 \%$ & $18.9 \%$ & $37.8 \%$ & $14.4 \%$ & 50 \\
\hline \multicolumn{3}{|c|}{ Mean(SD) Strongly disagree Disagree } & Unsure & Agree & Strongly agree & 0 \\
\hline
\end{tabular}

Figure 1B. Responses to the statement "Theory is complemented with practical work and/or experiments"

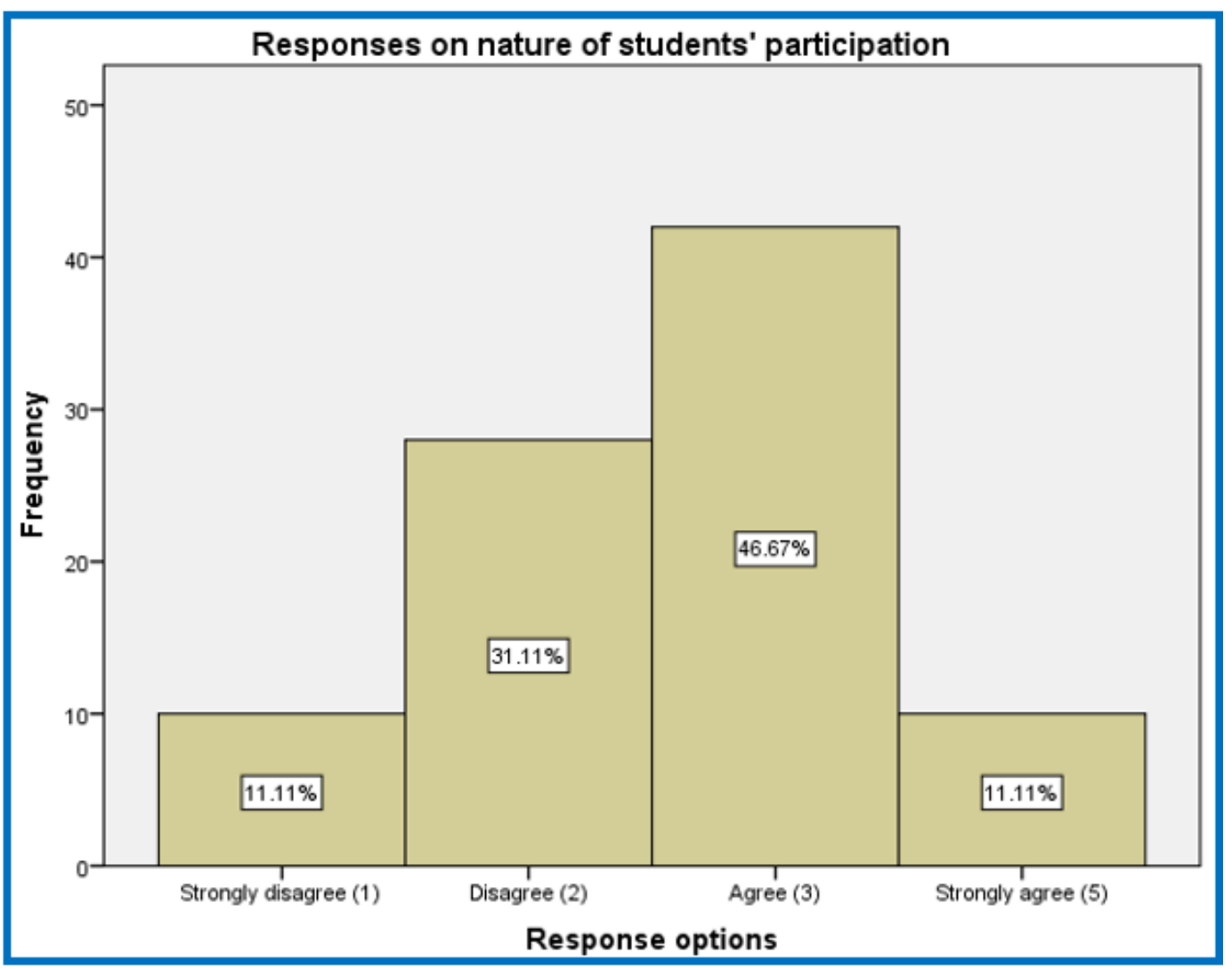

Figure 1C. Responses to the statement "Students actively participates during classes" 


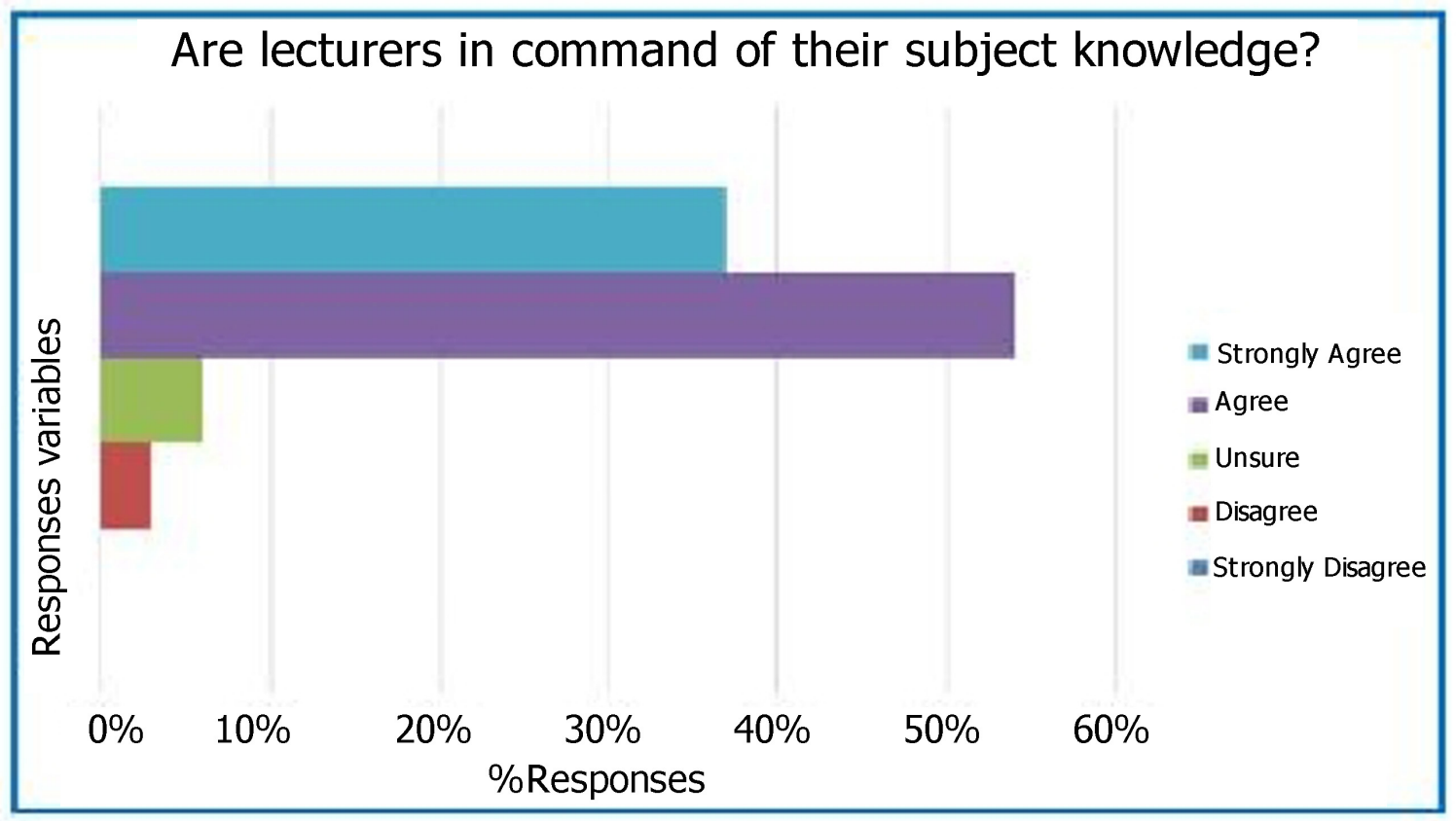

Figure 1D. Responses on the statement "Lecturers are always in command of the subject"

Figure 1. Main results on instructional strategies

Table 6. Interviewed students'perceptions of teaching methods/strategies

\begin{tabular}{|c|c|c|}
\hline Theme 4 & Category & Detailed responses \\
\hline \multirow{5}{*}{$\begin{array}{l}\text { Quality of } \\
\text { instruction }\end{array}$} & \multicolumn{2}{|l|}{ Teaching strategies } \\
\hline & $\begin{array}{l}\text { - Lecture method } \\
\text { - No groupwork } \\
\text { - Demonstration }\end{array}$ & $\begin{array}{l}\text { He teaches a lot of time, there is no group work, he teaches a lot and then he shows us some } \\
\text { of the things that we do not know like he gives us an example of maybe like a motor or } \\
\text { something like that, some other time he showed us how to do the switching stuff (ISB) } \\
\text { It is a method of a lecture that coming in and just teaching us, mainly the lecture method. } \\
\text { He does give a demonstration with some device or something. We haven't had group } \\
\text { work and debate happens amongst us students (ISC) } \\
\text { For Electrical Trade, our teacher usually shows us what he is talking about; if he says a } \\
\text { circuit breaker, he will bring a circuit breaker and show you this is a circuit breaker it works } \\
\text { like this, this is a switch he brings those things, the batteries also so he demonstrates, he } \\
\text { shows us and also uses projectors. He is the only one who uses a projector (ISF) }\end{array}$ \\
\hline & - Projector & $\begin{array}{l}\text { Sometimes they use demonstration like they demonstrate with machines and then they use } \\
\text { the projectors (ISA) }\end{array}$ \\
\hline & - Past question papers & $\begin{array}{l}\text { Lecture method and also, they give us previous question papers to do towards the end of the } \\
\text { trimester. They demonstrate also (ISD) }\end{array}$ \\
\hline & $\begin{array}{l}\text { - Class discussion not } \\
\text { encouraged }\end{array}$ & $\begin{array}{l}\text { They just teach us as a class. I would say he do demonstrations. You see most of the time } \\
\text { when a discussion happens, eeh we are told like no you can't do that do it at your own time } \\
\text { so I am not sure if class discussions are really applied (ISE) }\end{array}$ \\
\hline
\end{tabular}

Theme 4 for the interviews asked questions on instructional strategies as perceived by the students. There were eight questions that required responses on: teaching strategies used by the lecturer; complementarity of theory and practical work/experiments; teaching practices and academic achievement; lesson coherence; mastery of subject knowledge by the lecturer; how Electrical Trade Theory could be improved; as well as assessment and any other challenges faced. Extracts in Table 6 reveal key findings about students' perceptions of content emphasis

\section{Summary of Results on Instructional Resources}

Table 7 shows responses on instructional resources used in classrooms, laboratory or workshops.

Results showed that all the students believed that the textbook was the most used Learning and Teaching Support Material (LTSM). The lack of use of computers was another important finding regarding the instructional resources' component of OTL. This raises concerns that students might not be receiving sufficient OTL, especially on the internet and other computer-based learning 
platforms, such as simulations of complex electrical engineering concepts. Another finding was that few students $(12.2 \%)$ indicated that safety attire was used, which points to a similar conclusion reached about instructional strategies; that lessons in Electrical Trade Theory are largely theory-based, and deny students OTL.

Table 7. Responses on instructional resources used in classrooms, laboratory or workshops

\begin{tabular}{|c|c|c|c|}
\hline $\begin{array}{c}\text { Resource } \\
\text { No. }\end{array}$ & $\begin{array}{c}\text { Instructional } \\
\text { resource type }\end{array}$ & $\begin{array}{c}\text { Number of } \\
\text { respondents }\end{array}$ & $\begin{array}{c}\text { Response } \\
\text { percentage }\end{array}$ \\
\hline 8.1 .1 & Textbooks & 90 & $100 \%$ \\
\hline 8.1 .2 & Worksheets & 44 & $48.9 \%$ \\
\hline 8.1 .3 & Computers & 8 & $8.9 \%$ \\
\hline 8.1 .4 & Chalkboard & 14 & $15.6 \%$ \\
\hline 8.1 .5 & Whiteboard & 85 & $94.4 \%$ \\
\hline 8.1 .6 & Safety attire & 11 & $12.2 \%$ \\
\hline 8.1 .7 & Overhead projector & 63 & $70 \%$ \\
\hline 8.1 .8 & TV & 5 & $5.6 \%$ \\
\hline 8.1 .9 & Simulations & 8 & $8.9 \%$ \\
\hline 8.1 .10 & Posters & 18 & $20 \%$ \\
\hline
\end{tabular}

It also seems that access to workshops and laboratories was limited, as shown in Table 8.

Table 8. Responses on access to specialized equipment and facilities

\begin{tabular}{|c|c|c|}
\hline $\begin{array}{c}\text { Nature of access to } \\
\text { specialized equipment and } \\
\text { facilities }\end{array}$ & $\begin{array}{c}\text { Number of } \\
\text { respondents }\end{array}$ & $\begin{array}{c}\text { Response } \\
\text { percentage }\end{array}$ \\
\hline No access at all & 17 & $18.9 \%$ \\
\hline Limited access & 49 & $54.4 \%$ \\
\hline Access at most times & 16 & $17.8 \%$ \\
\hline Access at all times & 8 & $8.9 \%$ \\
\hline TOTAL & 90 & $100 \%$ \\
\hline
\end{tabular}

\section{Discussion}

Literature acknowledges that content coverage is related to student achievement [61]. In other words, student achievement is a function of content coverage. The attained curriculum is thus; a measure of what students has learned, as reflected by their achievements. It is our opinion that students should have the OTL all the N1 Electrical Trade Theory content on which they will be assessed. When a lecturer covers all the content as expected, he/she will be creating an opportunity for students to acquire and perform better, in relation to the necessary skills, knowledge and attitudes. An increase in the lecturer's content coverage of the N1 Electrical Trade Theory curriculum will, subsequently, lead to an increase in students' achievement in tests and examinations, as revealed by evidence from this study. This is encouraging, considering that poor performance is common in TVET colleges, evident from certification rates of between $29 \%$ and $41 \%$ [18] (see section on background and introduction).

At TVET colleges, the content to be covered is determined by the DHET, and is captured in the form of syllabuses. As found in the study, the N1 Electrical Trade Theory syllabus merely outlines the skeleton of the content to be covered. The importance of the lecturer's role is, therefore, in the planning and execution of the teaching and learning tasks that assist students to achieve the set learning outcomes. It is this implemented curriculum, more than the intended curriculum (syllabus) that is essential for improving student performance [36]. This study found that all the N1 Electrical Trade Theory curriculum topics were covered by the lecturer. Work that was not covered during normal classes was given to students to work through on their own. Butler, Schnellert and Perry [62] argue that work given to students to work through on their own enhances self-regulated learning. However, the absence of a monitoring mechanism on work done outside normal classes had the potential to deny the students an opportunity to fully learn the core curriculum of N1 Electrical Trade Theory. Feedback from both the students and the lecturer would have ascertained whether the students, indeed, covered such areas on their own or not; and the extent to which such content was covered.

Covering all the content may not be enough to create effective OTL for Electrical Trade Theory, without assessing how and why the content was covered. As revealed by the analysis of both the questionnaire and interview data, the lecturer was solely concerned about covering content and solving problems, which was confirmed by his use of a single textbook for teaching. As argued by Qualters [63], learning tasks need to leave room for examples from the student's own life. Content coverage that does not leave room for real-life examples may be interpreted as imposing a limitation on providing OTL for students studying N1 Electrical Trade Theory at a TVET college.

The discussion in this section is no longer on whether the curriculum was covered, but rather on the quality of the coverage (content emphasis). Content emphasis can be measured using different levels of cognitive demand. Closely linked to the understanding of Electrical engineering are the levels of content complexities [64] that students engage in during N1 Electrical Trade Theory classes. Therefore, for TVET students to acquire a deeper understanding of the subject Electrical Trade Theory, and sufficient learning activities must be done at appropriate cognitive levels as stipulated by the syllabus.

Document analysis of the 1996 syllabus currently being used in N1 Electrical Trade Theory revealed that cognitive demand levels for the examination questions were divided into four categories, namely; knowledge $( \pm 60 \%)$, understanding $( \pm 20 \%)$, application $( \pm 15 \%)$ and evaluation $( \pm 5 \%)$. The fact that a total of $80 \%$ of the examination questions' levels of demand, that is, knowledge $( \pm 60 \%)$ plus understanding $( \pm 20 \%)$ can be categorized as lower 
order, could lead to the interpretation that TVET college students expected much emphasis on lower-order skills, and less on higher-order skills. Students therefore, rarely expect to spend more time on skills that are considered by Carnoy et al. [64] and Kong et al. [65] to include problem-solving, inquiry and critical thinking, which are necessary for selecting and processing information. The opinion of Suryawati and Osman [66] is that, teaching and learning activities that are characterized by routines that do not allow for contextualized problem-solving and creativity impose an impediment to the provision of an effective OTL. This claim could also explain why the new TVET ICASS guidelines for Report 191 programme implementation from January 2018, refers to the higher-order skills of analysis and problem-solving. However, these guidelines do not indicate the weighting of these cognitive demand skills, leaving this crucial task to practitioners' (lecturers') discretion.

The third concern raised during the interviews was that the lecturer's teaching was based on past examination question papers. This finding is not surprising, as it echoes concerns expressed by Umalusi [67] on quality assurance for the National Accredited Technical Education Diploma (NATED) / (N) programmes in 2015, that some of the examination questions could have been easily spotted or predicted by students [67]. It would, therefore, be advisable to avoid repetition of the same or similar questions to previous exam papers.

The fourth concern was whether topics in N1 Electrical Trade Theory received the same attention. It is the assertion of the DHET [68] that having topics not receiving the correct emphasis, as stipulated by the syllabus weightings, has a strong bearing on how much work is covered, how teaching time is allocated, and how marks are allocated to a specific topic during assessment. Although findings from the quantitative data found that all topics received the same weighting, findings from the interview probing suggested otherwise. The students who were interviewed suggested that topics were not receiving attention according to syllabus stipulations. As advised by Kurz et al. [69], any deviation from the stipulated topic weightings results in a denial of students' OTL as planned in the intended curriculum.

It is Carroll [24]'s view that an OTL can, in general, be conceptualized as the amount of classroom time allowed for learning. Carroll goes on to define OTL as a learning model that mainly intends to measure the amount of time or exposure to a particular subject/content [19]. Therefore, no successful learning outcomes can be realized without sufficient teaching and learning time [70]. This study reveals that the allocated time for Electrical Trade Theory was spent on actual teaching and learning. Furthermore, students were attending their classes as scheduled; a practice that enhances their chances of performing well in the subject. The view of the relationship between class attendance, time spent on task and the enhancement of class performance is supported by a study conducted by Mohanan et al. [71] which found a positive correlation between class attendance and academic performance in both theory and practical examinations.

As argued by Gewer [14], TVET colleges are currently failing to achieve their goals in the area of developing practical skills in Electrical Engineering Studies. The absence of, or limited opportunities for, experiments and practical work in the workshops and laboratories indicated that a vital OTL Electrical engineering was missed. Experiments and practical work could result in, not only applied learning, but more importantly, in what Jacobs et al. [72] consider as a learning-centered instructional approach based on consideration of students' needs and general competencies; and that results in active students.

The syllabus was found to contribute to the current situation, where theory receives much more attention than practical work. An analysis of the syllabus revealed that there was an insignificant number of psychomotor skills stipulated in the learning outcomes of N1 Electrical Trade Theory. Students interviewed suggested that they would appreciate visiting industry in order to be exposed to more authentic environments. By learning under real-life conditions, TVET students would develop skills, knowledge and values at the highest level of Spady [73]'s demonstration mountain, namely; the context-dominated stage. This stage, which is also known as the transformational zone, is characterized by "integration, synthesis and application of complex content and competence under challenging job and societal contexts" [73p64]. More practical sessions are therefore, needed so that students can apply the theory they learnt in class to real-life examples, in order to enhance their OTL.

The main teaching methods identified during the students' interviews were the lecture and demonstration methods. These instructional approaches preferred by the lecturer were more teacher-centered, to the extent that not a single group work exercise was conducted during Electrical Trade Theory classes. The other related finding realized during interviews was that class discussions were discouraged, instead of being encouraged. This finding contradicts the TVET college stipulation of other teaching methods, such as small group work, class discussions, work sheets, surveys, brainstorming, role play and case study on the lesson plan template given to all the lecturers. As suggested by De Corte [74], learning should not be a "solo" activity, but should be anchored in real-life, social and physical contexts, and should involve exchanging ideas, comparing solutions and strategies and discussing relevant arguments. Furthermore, as revealed by literature, since Electrical engineering falls under student-centered, competence-based training [31-33]; instructional strategies should include problem-solving, research, small-group teaching and discussions [75,76].

During the interviews with students, it was noted that one of the challenges faced by students during classes was 
lack of prior knowledge. This challenge was exacerbated by the finding that the lesson pace was too fast for students lacking prior knowledge on the subject, and for mature students. The lecturer referred to these students as "dropouts"; an indication that these students had been failed by the conventional schooling system and, consequently, society in general. What was clear was that these students struggled in areas such as Mathematics and Science, which are prerequisites for understanding electrical engineering concepts. This finding seems to confirm that adequate prior knowledge can maximize the effectiveness of learning. A study by Song, Kalet and Plass [77] found that there is a direct, positive relationship between prior knowledge and learning.

As highlighted by Sedel [47], the challenges of ensuring education quality in Africa in general, are closely related to both the shortage of instructional resources and the inefficient use of the available resources. In this study, the lack of instructional resources, such as workshops, laboratories and computers, was raised by both the students and the lecturer. Inadequate instructional resources represent a severe drawback for creating OTL for students taking the subject N1 Electrical Trade Theory. The lack of resources, such as laboratories and workshops, leads to low-level acquisition of practical skills. As noted by Gewer [14], this such a lack could explain why the NATED programme in South Africa has failed to offer students much-needed practical learning activities and the opportunity to develop the necessary practical skills.

\section{Conclusion and Recommendations}

This study has discussed how OTL affects student learning and engagement in Electrical Engineering at a TVET college. Some of the challenges that were found to hinder the development of the expected skills include inadequate teaching and learning resources, inappropriate instructional strategies, and curriculum content. The study found that covering all the content or topics was not enough to create effective OTL. Attention needed also to be paid to how the allocated time was utilized, whether there was surface learning or deep learning. The role played by the lecturer in the creation of OTL for Electrical engineering through effective instructional strategies cannot be overemphasized. The lecturer should apply a variety of teaching methods inclusive of both young and mature students (TVET pedagogy and andragogy). The methods should result in instruction characterized by Electrical engineering theory, complemented by practice, scaffolding, self-regulated learning by students, improved classroom management skills, giving timely feedback and spending the allocated time on actual teaching and learning of the subject. TVET colleges should also focus on improving facilities, as this will go a long way to creating meaningful and effective opportunities for students to learn. Although OTL has been a promising lens that can help in constructing an explanation of why N1 engineering students may not perform well, further research is still required on how the concept of OTL can be used to further understand and characterize teaching and learning at TVET colleges.

\section{REFERENCES}

[1] Unesco, Actors and partnership in the vocational training sector, Unesco, Paris, 2018. URL: https://pefop.iiep.unesco.org/sites/default/files/ckeditor_file s/actors_and_partnerships_in_the_vocational_training_sect or_oct2018.pdf

[2] Fredriksen B, JP. Tan, "East Asia study tour. An overview of key insights," in An African exploration of the East Asian education experience, The World Bank, Washington, DC, 2008, pp. 1-60. URL:

https://openknowledge.worldbank.org/handle/10986/6424

[3] Seng LS, Case study on "national policies linking TVET with economic expansion: lessons from Singapore", Unesco, Singapore, 2011. URL:

http://www.unesco.org/new/fileadmin/MULTIMEDIA/HQ/ ED/pdf/gmr2012-ED-EFA-MRT-PI-07.pdf

[4] Agrawal T, "Vocational education and training programs (VET): An Asian perspective", Asia-Pacific Journal of Cooperative Education, vol. 14, no. 1, pp. 15-26, 2013.

[5] Rasool H, E. Mahembe, FET Colleges purpose in the developmental state: imperatives for South Africa, Human Resource Development Council of South Africa (HRDCSA), 2014. URL:

https://www.saben.ac.za/wp-content/uploads/2017/06/FETcolleges-purpose-in-the-developmental-state-Imperatives-fo r-SA.pdf

[6] DHET (Department of Higher Education and Training), White Paper for post- school education and training: building an expanded, effective and integrated post- school system, Government Printers, Pretoria, 2014.

[7] Oketch MO, "Education policy, vocational training, and the youth in sub- Saharan Africa," in African Youth and the persistence of marginalization: Employment, politics, and prospects for change, Routledge, London, 2015, pp. -151.

[8] Field S, Musset P, J-L, Álvarez-Galván, A skills beyond school review of South Africa. OECD Reviews of Vocational Education and Training, Organisation for Economic Co-operation and Development (OECD), Paris, 2014.

[9] Paterson A, Keevy J, K. Boka, Exploring a work-based values approach in South African TVET colleges to improve employability of youth: Literature review, JET Education Services, Johannesburg, 2017.

[10] RSA Commission of Inquiry into Higher and Tertiary Education, Report on the Commission of Inquiry into Higher and Tertiary Education and Training to the President of the Republic of South Africa, Government Printers, Pretoria, 2016. 
[11] RSA DoE (Republic of South Africa. Department of Education), Education White Paper 4: A programme for the transformation of further education and training: Preparing for the twenty-first century through education, training and work, Government Printer, Pretoria, 1998.

[12] Eicker F, Haseloff G, B. Lennartz, Vocational education and training in sub-Saharan Africa: Current situation and development, W. Bertelsmann Verlag, Bielefeld, 2017. URL:https://doi.org/10.3278/6004570w

[13] DHET (Department of Higher Education and Training), Statistics on post-school education and training in South Africa: 2016, Government Printers, Pretoria, 2018.

[14] Gewer DA, Managing growth and expansion in FET colleges, Human Resource Development Council for South Africa, Pretoria, 2013.

[15] Arfo EB, A comparative analysis of technical and vocational education and training policy in selected African countries [Unpublished Doctoral thesis]. University of KwaZulu-Natal, Durban, 2015.

[16] Ngure SW, Stakeholders' perceptions of technical, vocational education and training: the case of Kenyan micro and small enterprises in the motor vehicle service and repair industry [Published Doctoral thesis]. Edith Cowan University, Perth, 2013. URL:

http://ro.ecu.edu.au/theses/597

[17] Kraak A, "State policy failure in overcoming low employer demand for skills in South Africa," in Transformation audit 2014. Breaking the mould, Institute for Justice and Reconciliation, Cape Town, 2015, pp.1-11

[18] Badenhorst JW., RS. Radile, "Poor performance at TVET colleges: Conceptualising a distributed instructional leadership approach as a solution," Education Review, vol. 15, no. 3, pp. 91-112, 2018.

[19] McDonnell LM, “Opportunity to learn as a research concept and policy instrument," Educational Evaluation and Policy Analysis, vol. 17, pp. 305-322, 1995.

[20] Cooper R., DD. Liou, "The structure and culture of information pathways: Rethinking opportunity to learn in urban high schools during the ninth-grade transition," High School Journal, vol. 91, pp. 43-56, 2007.

[21] Boscardin CK., Aguirre-Muñoz Z., Stoker G., Kim J., Kim M., J. Lee, "Relationship between opportunity to learn and student performance on English and algebra assessments," Educational Assessment, vol. 10, no. 4, pp. 307-332, 2005.

[22] Chabongora BN., LC. Jita, "Opportunities to learn (OTL) Grade 10 algebra in three South African Catholic secondary schools," Journal of Educational Studies, vol. 12, no. 1, pp. 172-188, 2013.

[23] Burstein (Ed.) L, The IEA study of mathematics III: student growth and classroom processes, Pergamon Press, Oxford, 1993.

[24] Carroll J, "A model for school learning," Teachers College Record, vol. 64, pp. 723-733, 1963.

[25] Darling-Hammond L, The flat world and education: How America's commitment to equity will determine our future, Teachers College Press, New York, 2010.
[26] Floden R, "The measurement of opportunity to learn," in Methodological advances in cross-national surveys of educational achievement, National Academy Press, Washington, DC, 2002, pp. 231-266.

[27] König J., Bremerich-Vos A., Buchholtz C., Lammerding S., Strauß S., Fladung I., C. Schleiffer, "Modelling and validating the learning opportunities of preservice language teachers: on the key components of the curriculum for teacher education," European Journal of Teacher Education, vol. 40, no. 3, pp. 394-412, 2017. URL: https://doi.org/10.1080/02619768.2017.1315398

[28] Shavelson RJ, McDonnell LM, J. Oakes (Eds), Indicators for monitoring mathematics and science education, RAND Corporation, Santa Monica, CA, 1989.

[29] Thompson, DR., Senk, SL., "Documenting curriculum implementation: A case study from UCSMP geometry," in The Proceeding of $31^{\text {st }}$ Annual Meeting of the North American Chapter of the International Group for the Psychology of Mathematics Education, Atlanta, Georgia State University, Sept., 2009, pp. 847 - 854. URL: https://www.pmena.org/pmenaproceedings/PMENA\%2031 $\% 202009 \% 20$ Proceedings.pdf

[30] Herman JL, CD. Klein, Assessing opportunity to learn: A California example, National Center for Research on Evaluation, Standards, and Student Testing (CRESST), Los Angeles, CA, 1997.

[31] Unesco, Engineering: Issues, challenges and opportunities for development, Unesco, Paris, 2010. URL: https://www.acofi.edu.co/wp-content/uploads/2015/03/4.-D ocumento-Unesco-Ingenier\%C3\%ADa.pdf

[32] Oni B, Engineering: Electrical engineering - Report on CRAFTY Curriculum Foundations Project, Clemson University, South Carolina, 2000. URL: https://www.maa.org/sites/default/files/pdf/CUPM/crafty/C hapt8.pdf

[33] Kamanzi B, Decolonising the curriculum: The silent war for tomorrow, Daily Maverick, 2016 April 28. URL: www.dailymaverick.co.za/opinionista/2016-04-28-decoloni sing-the-curriculum-the-silent-war-for-tomorrow

[34] Brewer, DJ, C. Stacz, Enhancing opportunity to learn measures in NCES data, RAND Corporation, Santa Monica, CA, 1996.

[35] Stabback P, What makes a quality curriculum? In-progress reflection on current and critical issues in curriculum and learning, International Bureau of Education (IBE), Geneva, 2016.

[36] Bough C, "Using the curriculum to enhance teaching and learning," South African Journal of Science, vol. 114, no. 9/10, pp. 1-3, 2018.

[37] Allais S, "Will skills save us? Rethinking the relationships between vocational education, skills development policies, and social policy in South Africa, "International Journal of Education Development," vol. 32, no. 5, pp. 632-6422, 2012.

[38] Stevens FI, Witz L, M. Bailey, Teachers' evaluation of the sustainability of opportunity to learn (OTL) assessment strategies: A national survey of classroom teachers in large urban school districts, US Department of Education, Office 
of Educational Research and Improvement, Washington, DC, 1998.

[39] Reeves C., Carnoy M., N. Addy, “Comparing opportunity to learn and student achievement gains in Southern African primary schools: A new approach," International Journal of Educational Development, vol. 33, no. 5, pp. 426-435, 2013.

[40] Guirguis R., J. Pankowski, "Potential effects of teaching strategies on students' academic performance under a Trump administration," Journal of Education and Training Studies, vol. 5, no. 4, pp. 103-110, 2017.

[41] Ottmar ER., Konold TR., Berry RQ., Grissmer DW., C. Cameron, "Increasing equity and achievement in Fifth Grade mathematics: The contribution of content exposure," School Science and Mathematics, vol. 113, no. 7, pp. 345-355, 2013.

[42] Morris AK., Hiebert J., Berk D., A. Jansen, "Preparing teachers to learn from teaching," Journal of Teacher Education, vol. 58, no. 1, pp. 47-61, 2007.

[43] DHET (Department of Higher Education and Training), Green paper on post- school education and training, Government printers, Pretoria, 2012.

[44] Van der Bijl A., LJ. Oosthuizen, "Deficiencies in technical and vocational education and training lecturer involvement qualifications and its implications in the development of work related skills," South African Journal of Higher Education, vol. 33, no. 3, pp. 205-221, 2019. URL: https://doi.org/10.20853/33-3-2886

[45] Ramberger R, Dropping out: Why learners drop out of high school and what can be done, Harvard University Press, Cambridge, 2011.

[46] Lindblom-Ylänne S., Parpala A., L. Postareff, "What constitutes the surface approach to learning in the light of new empirical evidence?," Studies in Higher Education, vol. 44, no. 12, pp. 2183-2195, 2018. DOI: $10.1080 / 03075079.2018 .1482267$

[47] Sedel C, "Setting the scene," in The challenge of learning: improving the quality of basic education in sub-Saharan Africa, Association for the Development of Education in Africa, 2005, pp. 31-51.

[48] Field S, Musset P, J-L, Álvarez-Galván, A skills beyond school review of South Africa. OECD Reviews of Vocational Education and Training, Organisation for Economic Co-operation and Development (OECD), Paris, 2014.

[49] Czerniewicz L, Murray S, M. Probyn, A research paper on the role of learning support materials in Curriculum 2005, National Institute of Curriculum Research and Development, Department of Education, South Africa, 2000.

URL: https://www.researchgate.net/publication/29807389_Learn ing_support materials_LSMs and Curriculum 2005 C20 05_a_research_paper_on_the_role_of_learning_support_m aterials in Curriculum 2005

[50] Milligan LO., Koornhof H., Sapire I., L. Tikly, "Understanding the role of learning and teaching support materials in enabling learning for all," Compare: A Journal of Comparative and International Education, 2018. [online]. URL: https://doi.org/10.1080/03057925.2018.1431107
[51] Almalki S, "Integrating quantitative and qualitative data in mixed methods research: Challenges and benefits," Journal of Education and Learning, vol. 5, no. 3, pp. 288-296, 2016. URL: https://files.eric.ed.gov/fulltext/EJ1110464.pdf

[52] Berman EA, "An exploratory sequential mixed methods approach to understanding researchers' data management practices at UVM: Integrated findings to develop research data services", Journal of eScience Librarianship, vol. 6, no. 1, pp. e1104. URL: https://doi.org/10.7191/jeslib.2017.1104

[53] Yin RK, Qualitative research from start to finish 2nd ed, The Guilford Press, New York, 2016.

[54] Mohajan HK, "Qualitative research methodology in social sciences and related subjects," Journal of Economic Development, Environment and People, vol. 7, no. 1, pp. 23-48, 2018

[55] Mack N, Woodsong C, Macqueen KM, Guest G, E. Namey Qualitative research methods: A data collector's field guide, Family Health International, North Carolina, 2005.

[56] Creswell JW, Creswell, Research design: qualitative, quantitative, and mixed approaches, SAGE, London, 2018.

[57] Lee N., JW. Cadogan, "Problems with formative and high-order reflective variables," Journal of Business Research, vol. 66, no. 2, pp. 242-247, 2013.

[58] El-Hajjar S, "A statistical study to develop a reliable scale to evaluate instructors within higher institutions," WSEAS Transactions on Mathematics, vol.13, pp. 885-894, 2014.

[59] Zohrabi M, "Mixed method research: Instruments, validity, reliability and reporting findings," Theory and Practice in Language Studies, vol. 3, no. 2, pp. 254-262, 2013.

[60] RSA Education and Culture Service, Syllabus for Electrical Trade Theory N1, Government Printers, Pretoria, 1996.

[61] Schmidt W, Jorde D, Cogan L, Barrier E, Gonzalo I, Moser U, Shimizu K, Sawada T, Valverde G, McKnight C, Prawat R, Wiley D, Raizen S, E. Britton, Characterizing pedagogical flow: An investigation of mathematics and science teaching in six countries, Kluwer Academic Publishers, 1996.

[62] Butler DL, Schnellert L, NE. Perry, Developing self-regulating students, Pearson, Toronto, 2017.

[63] Qualters DM, "Bringing the outside in: Assessing experiential education," New Directions for Teaching and Learning, no. 124, pp. 55-62, 2010. DOI: 10.1002/tl.421

[64] Carnoy M., Chisholm L., H. Baloyi, "Uprooting bad mathematical performance: pilot study into roots of problems," HSRC Review, vol. 6, pp. 13-14, 2008.

[65] Kong SC., Chan TW., Griffin P., Hoppe U., Huang R., Kinshuk CK., Looi CK., Milrad M., Norris C., Nussbaum M., Sharples M., So WMW., Soloway E., S. Yu, "E-learning in school education in the coming 10 years for developing $21 \mathrm{st}$ century skills: critical research issues and policy implications," Educational Technology \& Society, vol. 17, no. 1, pp. 70-78, 2014.

[66] Suryawati E., K. Osman, "Contextual learning: Innovative approach towards the development of students' scientific attitude and natural science performance," EURASIA Journal of Mathematics, Science and Technology Education, 
vol. 14, no. 1, pp. 61-76, 2018.

[67] Umalusi, Report on the quality assurance of the examinations and assessment of the National Certificate (Vocational) and NATED (N2-N3) 2015, Umalusi, Pretoria, 2016.

[68] DHET (Department of Higher Education and Training), Internal Continuous Assessment (ICASS) guidelines for Report 191 programmes in TVET colleges, Government Printers, Pretoria, 2017.

[69] Kurz A., Elliot S.N., Wehby J.H., JL. Smithson, “Alignment of the intended, planned, and enacted curriculum in general and special education and its relation to student achievement," The Journal of Special Education, vol. 44, no. 3, pp. 131-145, 2010.

[70] Abadzi H, Absenteeism and beyond: Instructional time loss and consequences: World Bank Policy Research Working Paper No. 4376, The World Bank, Washington DC, 2007.

[71] Mohanan LK., Harichandran DT., SM. Vijayan, "Association of class attendance and academic performance of MBBS students in pharmacology - A retrospective cohort study," National Journal of Physiology, Pharmacy and Pharmacology, vol. 7, no. 10, pp. 1056-1060, 2017.
[72] Jacobs M, Vakalisa, NCG, N. Gawe, Teaching-learning dynamics, 5th ed, Pearson, Cape Town, 2017.

[73] Spady WG, Outcomes-based education: critical issues and answers, American Association of School Administrators, Arlington, 1994. URL:

https://files.eric.ed.gov/fulltext/ED380910.pdf

[74] De Corte E, "Historical developments in the understanding of learning," in The nature of learning. Using research to inspire practice, OECD Publishing, 2010, pp. 35-67.

[75] Anane CA, “Competency based training: Quality delivery for technical and vocational education and training (TVET) institutions," Educational Research International, vol. 2, no. 2, pp. 117-127, 2013. URL:

http://www.erint.savap.org.pk/PDF/Vol.2(2)/ERInt.2013(2. 2-14).pdf

[76] Boahin P., W. Hofman, "Perceived effects of competency-based training on the acquisition of professional skills," International Journal of Educational Development, vol. 36, pp. 81-89, 2014

[77] Song HS., Kalet AL., JL. Plass, "Interplay of prior knowledge, self-regulation and motivation in complex multimedia learning environments," Journal of Computer Assisted Learning, vol. 32, no. 1, pp. 31-50, 2016. 